Oana Panaïté, The Colonial Fortune in Contemporary Fiction in French. Liverpool:

Liverpool University Press, 2018. viii + 206 pp. (Cloth US\$120.00)

The Colonial Fortune in Contemporary Fiction in French is an ambitious project drawing together texts that have traditionally been treated separately due to their authors' disparate cultural and national backgrounds and their narrative focuses. Oana Panaïté aims specifically to bring into conversation works that are both directly and indirectly concerned with colonialism and postcolonialism in order to investigate what she terms "the colonial fortune." As she asserts in the introduction, the study "originated in an observation: the subtle yet persistent presence of the colonial in narratives not directly concerned with colonial history or issues such as immigration, multiculturalism or neocolonialism" (p. 1). From this premise, she introduces a striking and contrasting array of 16 authors who form the basis of her theoretical investigation into a paracolonial aesthetics. She sees this as a double phenomenon concerned with the "revival, resurgence and remanence ... of the colonial in today's political and cultural imaginary" on the one hand, and on the other, "the reimagining, revisiting and reassessment of the colonial in works of literature" (p. 4). The text includes both metropolitan and non-metropolitan writers and publications that date from 1967 (Claude Simon's Histoire) to 2013 (Il faut beaucoup aimer les hommes by Marie Darrieussecq, Ladivine by Marie Ndiaye, and Parabole du failli by Lyonel Trouillot). Panaïté's literary choices stem from her belief that "today's fiction writing is a transfrontier process" (p. 3) and that envisioning "these works from a paracolonial perspective makes possible a transversal reading that cuts across distinct poetics, national boundaries and colonial and postcolonial interpretive models" (p. 5).

The book is clearly and logically organized with an extensive introduction elucidating the theoretical focus, before leading on to three sections, each of which is helpfully introduced by a short overview: "From Exotic Destinations to Colonial Destinies," "Writing as Africans," and "Colonial Remanence." The final section then argues for a "paracolonial aesthetics." Overall, the text is written in a dense, technical style, which detracts somewhat from the flow of the narrative. The introduction is particularly heavy on terms and jargon as Panaïté seeks to define her theoretical stance. The meticulous close readings of the primary texts in the first three sections reveal an impressive level of scholarship. However, it is the final section, and in particular its discussion of Trouillot's Parabole du failli, Régis Jauffret's Microfictions, and Léonora Miano's Soulfood équatoriale, that provide the most interesting insights into the possibilities 
of Panaïtés theme and the powerful role that literature can play in reimagining contemporary concerns.

Unfortunately, there are a number of glaring proofreading errors in the text, including referring to well-known critic J. Michael Dash as Michael J. Dash twice in the text and again in the index and stating that the much-publicized Taubira law of 2001 recognized the Atlantic slave trade and slavery as "laws against humanity" rather than as "crimes against humanity" (p. 171). Reference to this law is also absent from the index. Moreover, Trouillot's text which forms part of the primary corpus is incorrectly referred to throughout the book as $\mathrm{La}$ Parabole du failli rather than Parabole du failli and Miano's book is listed in the primary texts as Souldfood équatoriale. Given the intricate detailing of texts, theories, and authors throughout the text, it is a shame to be let down by such simple oversights.

However, Panaïtés book makes a valuable contribution to the field of colonial and postcolonial studies. By bringing together authors and texts normally studied in isolation from each other, she opens up the way for novel perspectives on the place of colonialism in the contemporary world. As she argues,

literature and theory can shed light on the burdensome, incommensurable and indivisible colonial heritage that continues to shape our era's violent struggles, ideological incomprehensions and myopic or even catastrophic public policies. They can show that reckoning with irreconcilable visions of the past may lead to imagining a common future and they can call to a particular kind of action in which powerful emotions foster careful reflection.

pp. $184-85$

The Colonial Fortune will no doubt be the first step in a renewed way of engaging with the complexities of the past and its role in shaping the present and future.

\section{Bonnie Thomas}

French Studies, The University of Western Australia bonnie.thomas@uwa.edu.au 